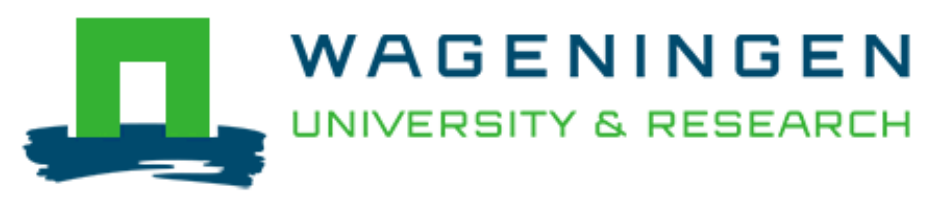

\author{
Oxidative stability of soy proteins: From ground soybeans to structured \\ products \\ Duque-Estrada, P., Kyriakopoulou, K., de Groot, W., van der Goot, A. J., \& \\ Berton-Carabin, C. C.
}

This is a "Post-Print" accepted manuscript, which has been Published in "Food Chemistry"

This version is distributed under a non-commercial no derivatives Creative Commons (c) (1) (3) $\Theta$ reproduction in any medium, provided the original work is properly cited and not used for commercial purposes. Further, the restriction applies that if you remix, transform, or build upon the material, you may not distribute the modified material.

Please cite this publication as follows:

Duque-Estrada, P., Kyriakopoulou, K., de Groot, W., van der Goot, A. J., \& BertonCarabin, C. C. (2020). Oxidative stability of soy proteins: From ground soybeans to structured products. Food Chemistry, 318, [126499].

https://doi.org/10.1016/j.foodchem.2020.126499

You can download the published version at:

https://doi.org/10.1016/j.foodchem.2020.126499 


\section{Oxidative stability of soy proteins: from ground soybeans to structured products}

Patrícia Duque-Estrada, Konstantina Kyriakopoulou, Wouter de Groot, Atze Jan van der Goot, Claire C. Berton-Carabin*

Food Process Engineering, Wageningen University \& Research, PO Box 17, 6700 AA,

Wageningen, The Netherlands

*Corresponding author. Tel.: +31 (0)3174-85447; claire.carabin-berton@wur.nl (C. C. BertonCarabin). 


\section{Abstract}

1 The production of soy protein-based foods requires multiple-step, intensive processing

2 and storage of soy ingredients, which can increase the product's susceptibility to

3 oxidation. Therefore, we investigated the oxidative stability of soy protein-based products

4 subjected to different relevant conditions or treatments: over storage of soy flours, over

5 fractionation of to yield soy protein isolate (SPI), and over subsequent thermomechanical

6 processing to yield a model structured product. Soy flours were stable to lipid and protein

7 oxidation over 250 days storage in chilled or ambient conditions. The fractionation process

8 applied to make SPI did not increase substantially protein carbonylation, but increased

9 surface-exposed hydrophobicity and decreased free thiols, compared to the starting

10 defatted flour. Subsequent processing of hydrated SPI powder at $140{ }^{\circ} \mathrm{C}$ further increased

11 protein carbonylation to a high extent. Therefore, we conclude that soy flours can be stable

12 over long storage times, but processing to yield structured foods products promote protein

13 oxidation.

14

15 Keywords: soy protein isolate, protein oxidation, carbonylation, thiols, lipid oxidation 


\section{Introduction}

17 Soy proteins have been widely used in food industry due to their functionality and high nutritional value. Different soy protein ingredients can be obtained through processing of soybeans in various conditions: full-fat soy flour (FFSF) is obtained through soybean milling; defatted soy flour (DSF) is obtained after oil extraction from FFSF, and lastly soy protein concentrate (SPC) and isolate (SPI) are obtained after wet fractionation processes. For instance, solubilization under alkali and precipitation under acid conditions. The final stage of the fractionation process involves drying, which is usually done by spray-drying (large scale) or freeze-drying (lab-scale). The final soy protein ingredients, SPC and SPI, contain the major soybean storage proteins, $\beta$-conglycinin and glycinin. SPC usually contains $>65 \%$ proteins in dry basis and SPI $>90 \%$ proteins.

The interest in soy protein ingredients aligns with the increased demand for alternatives to meat proteins, as soy proteins can be used as the main source of protein in the final product. Therefore, enzymatic oxidation, which involves the presence of the enzyme lipoxygenase (LOX). 
Lipid oxidation products, as well as reactive oxygen species, can react with proteins, leading to protein oxidation (Estévez, 2017). Such co-oxidation phenomenon is relevant to FFSF, but may also play a role in DSF in which traces of unsaturated lipids can be present still. Studies have shown that adding unsaturated lipids to DSF or directly to the SPI induced protein oxidation in SPI (Boatright \& Hettiarachchy, 1995; Huang, Hua, \& Qiu, 2006). Protein oxidation results in modifications of amino acid side chains and of the protein backbone, such as carbonylation, fragmentation or crosslinking (Estévez, 2017; Hellwig, 2019). Protein oxidative modifications can thus lead to changes in protein structure and conformation. Some of these modifications involve changes in protein hydrophobicity and loss of essential amino acids, which can affect protein solubility, nutritional value, and recently a few studies have even associated it to harmful effects in vivo (Estévez \& Xiong, 2019).

So far, most of the research on the oxidative stability of SPI has focused on the ability of lipid oxidation products to induce protein oxidation (Cucu et al., 2013; Huang et al., 2006; Wu, Zhang, \& Hua, 2009), but limited information is available about how the processes applied to obtain soy flours and derived protein ingredients affect protein oxidation. In our lab, we recently measured the protein-bound carbonyl content of several commercial SPC and SPI powders, and compared it to values reported in literature for different plant and animal proteins (Fig. S1 in supplementary material). All the tested commercial ingredients had a higher carbonyl content than e.g., lab-made SPI as reported in literature (Chen, Zhao, Sun, Ren, \& Cui, 2013; Wu et al., 2009). Compared to these commercial soy protein ingredients, the carbonyl contents for lupine protein isolate, whey protein isolate (WPI), raw chicken and bovine meat were also lower (Berghout, Marmolejo-Garcia, Berton-Carabin, Nikiforidis, Boom, \& van der Goot, 2015; Berton-Carabin, Schröder, Rovalino-Cordova, Schroën, \& Sagis, 2016; Santé-Lhoutellier, Astruc, Marinova, Greve, \& Gatellier, 2008; Soyer, Özalp, Dalmiş, \& Bilgin, 2010). Such a variability in the protein-bound carbonyl levels suggests that either the process to obtain soy 
protein ingredients, and/or the subsequent storage conditions promote protein oxidation. Interestingly, it was previously reported that SPI flours have more carbon-centered radicals than animal protein ingredients such as WPI (Boatright, Lei, \& Jahan, 2009). The release of those radicals increased during storage and upon hydration (Boatright et al., 2009). These results suggest that soy protein ingredients may be particularly prone to oxidation, especially in hydrated form.

Soy protein ingredients are frequently used to formulate structured food products, which involves further processing. These processes often use high temperatures, which can promote lipid and protein oxidation. Recently, we found that the carbonyl content increased in hydrated SPC when subjected to a thermomechanical process (Duque Estrada, Berton-Carabin, Schlangen, Haagsma, Pierucci, \& van der Goot 2018). Therefore, we hypothesize that protein oxidation products are formed during the initial ingredient fractionation process, and that soy flours containing lipids are more prone to oxidation during storage at ambient conditions, i.e., at room temperature $\left(\sim 25^{\circ} \mathrm{C}\right)$. In addition, protein oxidation occurring in the thermomechanical process depends on the initial oxidative state of the ingredient.

Therefore, we aimed to understand the impact of storage and processing, fractionation and heating, on protein oxidation of soy proteins. For this, we investigated the oxidative stability of house-made FFSF and DSF stored at different temperatures for up to 250 days; and protein oxidation upon wet fractionation process of DSF to yield lab-made SPI. Finally, we also investigated how protein oxidation in SPI was further affected by applying a thermomechanical process, which would be the ultimate step towards final product fabrication. We used proteinbound carbonyl as a marker for protein oxidation, as well as complementary analyses such as the determination of the concentration of thiol groups and protein aggregation. 


\section{Material and methods}

89

\subsection{Materials}

Soybeans were obtained from FRANK Food Products (Twello, The Netherlands) and stored for less than 1 year at $4{ }^{\circ} \mathrm{C}$. According to the manufacturer, soybeans did not receive any postharvesting treatment. SPI (SUPRO ${ }^{\circledR} 500$ E- $80.16 \%$ protein) was obtained from Danisco (Copenhagen, Denmark) ( $\mathrm{N}$ x 5.7) and had been stored in a closed plastic container at room temperature $\left(\sim 25^{\circ} \mathrm{C}\right)$ for at most 13 months before the start of the experiments. 8-Anilino-1napthalensulfonic acid ammonium salt (ANSA, $\geq 97 \%$ ), $\beta$-mercaptoethanol, sodium phosphate monobasic dihydrate $(\geq 99 \%)$, sodium phosphate dibasic $(\geq 99 \%)$, 2,4dinitrophenylhydrazine (DNPH), trichloroacetic acid (TCA), sodium dodecyl sulfate (SDS), guanidine hydrochloride $\left(\mathrm{CH}_{5} \mathrm{~N}_{3} \mathrm{HCl}\right)$, cumene hydroperoxide solution $(80 \%)$, n-hexane, $p$ anisidine, Ellman's reagent or 5,5'-dithiobis (2-nitrobenzoic acid) (DTNB) and Bis-TRIS buffer were obtained from Sigma-Aldrich (Germany, Darmstadt). Hydrochloric acid (HCl, 37\%) was purchased from VWR Chemicals (Fontenay-sous-Bois, France). Ethanol (ACS $99 \%$ ), ethyl acetate (ACS 99\%), barium chloride $\left(\mathrm{BaCl}_{2} \cdot 2 \mathrm{H}_{2} \mathrm{O}\right)$, sodium hydroxide $(\mathrm{NaOH})$, ammonium thiocyanate $\left(\mathrm{NH}_{4} \mathrm{SCN}\right)$, 1-butanol, acetic acid (glacial) $100 \%$ were purchased from Emsure (Merck Millipore, Darmstadt, Germany). Ferrous sulfate heptahydrate $\left(\mathrm{FeSO}_{4} \cdot 7 \mathrm{H}_{2} \mathrm{O}\right)$ and methanol were obtained from Actu-All Chemicals B.V. (Oss, The Netherlands). Petroleum ether was obtained from Avantor Performance Materials B.V. (Deventer, The Netherland). The bicinchoninic acid (BCA) protein assay kit was obtained from Thermo Scientific (Pierce, Rockford, US). Mini-Protean TGX gels (12\%), Bio-safe Coomassie G-250 stain, 2x Laemmli sample buffer, 10x Tris/Glycine/SDS buffer (25 mM Tris, $192 \mathrm{mM}$ glycine and $0.1 \mathrm{w} / \mathrm{v} \%$ SDS, 1x solution, $\mathrm{pH} 8.3$ ) and precision plus protein dual color standard were purchase from Bio-Rad Laboratories (Munchen, Germany). Ultrapure 
water obtained from Millipore Milli-Q system was used for all experiments, unless otherwise stated.

\subsection{Preparation of soy flours: FFSF and DSF}

Soybeans were pre-milled using a pin mill (Condux-Werk LV 15 M, Wolfgang bei Hanau, Germany), followed by milling using a ZPS 50 impact mill (Hosokawa-Alpine, Augsburg, Germany). The conditions were set to: classifier wheel speed at $2500 \mathrm{rpm}$, air flow of $80 \mathrm{~m}^{3} / \mathrm{h}$, mill speed of 8000 rpm and feed rate of 2-5 rpm (Geerts, Dekkers, van der Padt, \& van der Goot, 2018). The milling process resulted in a fine flour with an average particle size of $80.3 \pm 6.8$ $\mu \mathrm{m}\left(D_{50}\right)$, as measured according to Xing, Wit, Kyriakopoulou, Boom, \& Schutyser (2018). Part of the obtained FFSF was immediately defatted using an automated Buchi extraction system B811 LSV (BÜCHI Labortechnik AG, Flawil, Switzerland) according to AACC method 30-25 (AACC, 1983). We performed a short standard Soxhlet procedure according to Berghout et al. (2015b) with slight modifications, in which the heating step of the standard procedure was reduced to $3 \mathrm{~h}$ to avoid that long extraction and solvent evaporation. The oil was extracted with petroleum ether $(1: 3.5 \mathrm{w} / \mathrm{w})$ for $3 \mathrm{~h}$ followed by $20 \mathrm{~min}$ solvent removal in a rotor evaporator RC900 (KNF, Trenton, US) at $65^{\circ} \mathrm{C}, 160 \mathrm{rpm}$ and 50 bar. The oil recovered was stored in plastic containers covered with aluminium foil and stored at $4{ }^{\circ} \mathrm{C}$ for analysis on the next day. The remaining solvent present in the DSF was evaporated overnight at room temperature $\left(\sim 25^{\circ} \mathrm{C}\right)$ while being protected from light exposure. On the next day, part of the obtained DSF was used for wet fractionation process.

Regarding storage conditions, both FFSF and DSF were stored in individual plastic containers closed with a lid and covered the outside of the container with aluminium foil to avoid exposure to light. One container was used per each day of analysis. Samples were stored at room temperature $\left(\sim 25^{\circ} \mathrm{C}\right), 4{ }^{\circ} \mathrm{C}$ and $-20{ }^{\circ} \mathrm{C}$, for 250 days. The temperatures of $25^{\circ} \mathrm{C}$ and $4{ }^{\circ} \mathrm{C}$ were 
chosen since protein-based flours and powders are usually stored at this range of temperatures. At $-20{ }^{\circ} \mathrm{C}$ it has been shown that meat products can undergo protein oxidation (Utrera, Parra, \& Estévez, 2014).

During storage conditions experiments, the same defatting procedure was repeated at different time points to extract the oil from FFSF and analyze it.

\subsection{Wet fractionation process}

Wet fractionation was performed to prepare SPI from DSF according to Jiang, Chen and Xiong (2009) with some adjustments. After solvent evaporation, DSF was suspended in ultrapure water (1:9 w/v) and the $\mathrm{pH}$ was adjusted to 8.0 using $1 \mathrm{M} \mathrm{NaOH}$. The sample was stirred for $3 \mathrm{~h}$, followed by centrifugation at $10,000 \mathrm{rpm}$ corresponding to $17,217 \mathrm{~g}$ for $30 \mathrm{~min}$ at $4{ }^{\circ} \mathrm{C}$ using a Sorvall Lynx 4000 centrifuge (radius of $15.4 \mathrm{~cm}$ ) (Thermo Fisher Scientific, Waltham, MA, USA). The supernatant was collected and adjusted to $\mathrm{pH} 4.5$ with $1 \mathrm{M} \mathrm{HCl}$. After $1 \mathrm{~h}$ stirring the suspension was centrifuged at $17,217 \mathrm{~g}$ at $4{ }^{\circ} \mathrm{C}$ for $30 \mathrm{~min}$. The protein pellet was washed with ultrapure water $(1: 4 \mathrm{w} / \mathrm{v})$ twice and stirred for $1 \mathrm{~h}$. Subsequently, the suspension was centrifuged at $8000 \mathrm{rpm}$ corresponding to $11,019 \mathrm{~g}$ for $30 \mathrm{~min}$ at $4{ }^{\circ} \mathrm{C}$. The protein pellet was suspended $(1: 4 \mathrm{w} / \mathrm{v})$ in ultrapure water and the $\mathrm{pH}$ was adjusted to 7.0 using $1 \mathrm{M} \mathrm{NaOH}$. This protein suspension was left stirring (with regular $\mathrm{pH}$ adjustments to 7.0 if necessary) at 1000 rpm for 2-3 h, until the $\mathrm{pH}$ was stable. The suspension was frozen overnight, and on the next day, freeze-dried for $72 \mathrm{~h}$ using a Christ Epsilon 2-6D freeze-dryer (Martin Christ Gefriertrocknungsanlagen GmbH, Osterode am Harz, Germany). After freeze-drying, SPI was then pulverized by using a Rotor Mill Pulverisette 14 (Fritsch GmbH, Idar-Oberstein, Germany) with a sieving ring with diameter $0.5 \mu \mathrm{m}$ and a speed of $6000 \mathrm{rpm}$. The samples were stored at $4{ }^{\circ} \mathrm{C}$ for further analysis. 


\subsection{Chemical and physical properties of soy flours}

160 The moisture content of FFSF, DSF and SPI was determined by drying $3 \mathrm{~g}$ sample at $105^{\circ} \mathrm{C}$ 161 until constant weight in an oven (Binder GmbH, Tuttlingen, Germany). The total protein content 162 was determined by nitrogen content with the Dumas method using a Flash EA 1112 series N163 analyzer (Thermo Fisher Scientific, Waltham, MA, USA) with a nitrogen conversion factor of 164 5.7. The soluble protein concentration was determined by bicinchoninic acid (BCA) assay 165 according to the manufacturer's specifications with a few modifications (Duque Estrada et al., 166 2018). The oil content was determined by Soxhlet as described in section 2.2. The ash content 167 was determined in $1 \mathrm{~g}$ of sample heated at $525{ }^{\circ} \mathrm{C}$ for $5 \mathrm{~h}$ using ashing furnace AAF $11 / 3$ 168 (Carbolite-Gero Ltd., Hope, UK), with a ramp rate of $15^{\circ} \mathrm{C} / \mathrm{min}$. Afterward, the samples were 169 left in a desiccator until constant weight. The water activity of FFSF, DSF, and SPI was 170 measured at $25^{\circ} \mathrm{C}$ in an Aqualab water activity meter (Decagon Devices Inc., Pullman, WA, 171 US). LOX activity in FFSF was determined by measuring the formation of conjugated (CD), 172 according to Kong, Li, Wang, Hua, \& Huang (2008). Briefly, the supernatant of FFSF 173 suspension (2.4 wt.\% in water) was added with $2.24 \mathrm{mM}$ linoleic acid suspension ( $50 \mathrm{mM}$ 174 borate buffer, $\mathrm{pH}$ 8.6), and the mixture was rapidly shaken and incubated for 4 minutes at 30 $175{ }^{\circ} \mathrm{C}$ in a water bath.. Samples were regularly taken in time, and the absorbance was recorded at $176234 \mathrm{~nm}$. One unit (U) of LOX was defined as the quantity of enzyme that generates $1 \mu \mathrm{mol}$ of $177 \mathrm{CD}$ per minute upon incubation at $30^{\circ} \mathrm{C}$. To determine the rate of formation of $\mathrm{CD}$ in $\mu \mathrm{mol} \mathrm{min}$ 178 , we used the following calculation (Eq. 1):

$$
\mathrm{CD}=\frac{\left[\frac{A b s}{t}\right] S_{V^{*}} 10^{6}}{\mathcal{E} * l} \quad \text { Eq. } 1
$$


Where $A b s$ is the absorbance at $234 \mathrm{~nm}, t$ is the time in $\min , S_{V}$ is the sample volume in $\mathrm{L}, \mathcal{E}$ is the molar extinction coefficient of $\mathrm{CD}\left(2.5 \times 10^{4} \mathrm{M}^{-1} \mathrm{~cm}^{-1}\right)$ and $l$ is the cuvette length in $\mathrm{cm}$. LOX activity was expressed in unit (U) per $\mathrm{mL}$

The results of the analysis are presented in Table S1 in supplementary material. All measurements were done in triplicate on two independent batches, except for water activity for which independent batches were measured in duplicate.

\subsection{Thermomechanical process of SPI}

SPI samples were subjected to a heat- and shear-based process in a closed cavity (disk geometry) rheometer (CCR) (RPA elite, TA instruments, US) to mimic the conditions encountered in a high-temperature shear cell, according to Geerts et al. (2018). The CCR can be used as a tool to study the rheological properties of concentrated biopolymer matrices under mechanical stress and high temperatures conditions. The hydrated powders were prepared with $44 \mathrm{wt} \%$ SPI, 55 wt $\%$ demineralized water and $1 \mathrm{wt} \% \mathrm{NaCl}$ according to Geerts et al. 2018. After mixing the ingredients and resting for $30 \mathrm{~min}$, approximately $3 \mathrm{~g}$ of the mixture were placed in the CCR, which was sealed with a closing pressure of 4.5 bar to prevent water evaporation. A time-sweep was performed at $80 \%$ strain and $10 \mathrm{~Hz}$ frequency while heating at 100 or $140{ }^{\circ} \mathrm{C}$ for $15 \mathrm{~min}$. The resulting samples were then cooled down to room temperature $\left(\sim 25^{\circ} \mathrm{C}\right)$ and stored at $4{ }^{\circ} \mathrm{C}$ until further analysis.

\subsection{Preparation of soy protein suspensions to measure protein oxidation}

Suspensions of the soy protein ingredients (FFSF, DSF and SPI) were prepared with $6 \mathrm{wt} \%$ protein (based on protein content in dry basis) in ultrapure water or in $10 \mathrm{mM}$ sodium phosphate buffer $\mathrm{pH} 7.0$, when mentioned. The samples were quickly vortexed at $2500 \mathrm{rpm}$ and then mixed at 1980 rpm in a Multi Reax shaker (Heidolph Instruments GmbH \& CO, Schwabach, Germany) 

soluble fraction was recovered.

The processed SPI-based samples were first cut into small pieces, then homogenized with ultrapure water to prepare a $6 \mathrm{wt} \%$ protein suspension using a rotor-stator homogenizer (IKA

207 T18 UltraTurrax, Thermo Fisher Scientific, Staufen, Germany) at $13600 \mathrm{rpm}$ for $1 \mathrm{~min}$. 208 Afterwards the homogenate was centrifuged at $18,000 \mathrm{~g}$ at $2{ }^{\circ} \mathrm{C}$ for $20 \mathrm{~min}$ and the supernatant 209 was recovered. The soluble protein concentration was measured with the BCA assay as 210 described in section 2.4. The percentage of soluble protein in the supernatant compared to the 211 initial total protein content (based on protein content in dry basis) was determined (Fig. S2 in 212 supplementary material).

\section{2.7. Determination of protein-bound carbonyl content}

214 The determination of protein-bound carbonyl content was done according to Duque Estrada et 215 al. (2018). In the current paper, only the fraction obtained after the first centrifugation step was 216 considered since solubilization of soy flours was not an issue. Aliquots from the protein fractions 217 (section 2.6) (at least $4 \mathrm{mg} / \mathrm{mL}$ soluble protein) were taken to measure the carbonyl content by 218 the DNPH method. After the hydrazone derivatization, the pellets were suspended in $1.5 \mathrm{~mL}$ of $2196 \mathrm{M}$ guanidine hydrochloride prepared in $20 \mathrm{mM}$ sodium phosphate buffer ( $\mathrm{pH}$ 6.5) and 220 incubated in an Eppendorf thermomixer (Eppendorf AG, Germany) at $37^{\circ} \mathrm{C}$ overnight. Then, 221 the absorbance was measured at $370 \mathrm{~nm}$ using a UV-visible spectrophotometer (HACH Lange 222 DR 3900). A blank was prepared by following the exact same procedure, but without DNPH. 223 The soluble protein concentration in $6 \mathrm{M}$ guanidine hydrochloride was determined by the BCA 224 method. The carbonyl content was calculated with the following equation:

$$
\text { Carbonyl content }\left(\frac{\mathrm{mmol}}{\mathrm{kg}}\right)=\frac{\frac{A B S_{\text {sample }}-A B S_{\text {blank }}}{\varepsilon}}{\text { soluble protein concentration }} \quad \text { Eq. } 2
$$


Where, $A B S_{\text {sample }}$ is the absorbance of the sample, $A B S_{\text {blank }}$ the absorbance of the blank and $\mathcal{E}$ is the molar extinction coefficient of carbonyls set as $22000 \mathrm{M}^{-1} \mathrm{~cm}^{-1}$.

\subsection{Lipid oxidation: primary and secondary products}

\subsubsection{Hydroperoxide concentration}

230 The formation of hydroperoxides in the oil extracted from FFSF, freshly prepared or upon 231 storage in various conditions, was measured according to Berghout et al. (2015b). The oil was mixed with n-hexane in a 1:60 w/v ratio. Then the solution was vortexed for $30 \mathrm{~s}$. The assay reagent was prepared as follows: equal volumes of $0.144 \mathrm{M}$ ferrous sulfate heptahydrate $\left(\mathrm{FeSO}_{4}\right.$

$234.7 \mathrm{H}_{2} \mathrm{O}$ ) were mixed with $0.132 \mathrm{M} \mathrm{BaCl}_{2}$ in $0.4 \mathrm{M} \mathrm{HCl}$, then centrifuged for 3 min at 20,238g using the Eppendorf Centrifuge 5424 (Eppendorf AG, Hamburg, Germany). The supernatant was collected and mixed with $3.94 \mathrm{M}$ ammonium thiocyanate in equal volumes. The later solution was the assay reagent. Then, $1.40 \mathrm{~mL}$ methanol-butanol $(3: 1 \mathrm{v} / \mathrm{v})$ was mixed with 0.10 $\mathrm{mL}$ oil/n-hexane sample and $15 \mu \mathrm{L}$ assay reagent. The samples were covered, mixed and incubated for $20 \mathrm{~min}$. After the $20 \mathrm{~min}$ incubation, the absorbance was measured at $510 \mathrm{~nm}$ using a Beckman Coulter DU 720 UV/VIS spectrophotometer (Beckman Coulter, Brea, CA, USA) in polystyrene cuvettes. A calibration curve was prepared from a stock $5.26 \mathrm{mM}$ cumene peroxide solution (80\%) with a concentration range of $0-160 \mu \mathrm{M}$ to calculate the amount of peroxide in the oil samples. The hydroperoxide concentration $\left(C_{H P X}\right)$ was then calculated with

244 the following equation:

$$
C_{H P X}(\text { meq } / \mathrm{kg} \text { oil })=\frac{\text { mmol peroxide }}{2 * k g \text { of oil }} \text { Eq. } 3
$$

246 in which 2 was the conversion factor from mmol to meq $\mathrm{O}_{2}$. 
248 The secondary lipid oxidation products, mainly aldehydes, was measured by the para-anisidine 249 value (pAV) in the oil extracted from fresh FFSF or stored flours in various conditions. The 250 pAV was determined according to Berghout et al. (2015b). The oil/n-hexane mixture was 251 prepared as described in section 2.8.1. First, the absorbance of $1.2 \mathrm{~mL}$ of the oil/n-hexane mixture was measured at $350 \mathrm{~nm}$ using a Beckman Coulter DU 720 UV/VIS spectrophotometer (Beckman Coulter, Brea, CA, USA) in quartz cuvettes. A blank of pure n-hexane was used. Then, $1 \mathrm{~mL}$ of oil/n-hexane mixture was mixed with $0.2 \mathrm{~mL}$ of $2.5 \mathrm{~g} / \mathrm{L}$ p-anisidine/acetic acid solution. The resulting mixture was vortexed at $2500 \mathrm{rpm}$ for $10 \mathrm{~s}$ and incubated for $10 \mathrm{~min}$ in the dark. The blank was pure $n$-hexane with p-anisidine. After 10 min incubation, the absorbance was measured at $350 \mathrm{~nm}$. To calculate the pAV (arbitrary units), the following equation was used:

$$
\mathrm{pAV}=\frac{1.2 A s-A b}{m} \mathrm{Eq} .4
$$

in which $A s$ is the absorbance of the sample, $A b$ is the absorbance of the blank and $m$ the mass (g) of oil per mL n-hexane.

\subsection{Determination of thiol groups (free sulfhydryl groups)}

The free thiol group concentration was measured according to Berghout, Boom, \& van der Goot.

264 (2015a). The supernatants of FFSF, DSF and SPI suspensions prepared as described in section 2652.6 were diluted to a final soluble protein concentration of $5 \mathrm{~g} / \mathrm{L}$. Then, in a $15-\mathrm{mL}$ tube, $0.2 \mathrm{~mL}$ sample was added to $2.55 \mathrm{~mL}$ of $50 \mathrm{mM}$ Bis-TRIS buffer (pH 7.0) and to $0.25 \mathrm{~mL}$ DTNB solution $(0.1 \%(\mathrm{w} / \mathrm{v})$ Bis-TRIS buffer). The tubes were protected from light and mixed. After a total incubation time of $15 \mathrm{~min}$, the absorbance was measured at $412 \mathrm{~nm}$ with a spectrophotometer UV-VIS Beckman Coulter DU-720 (Woerden, the Netherlands). Two blanks 
were prepared to correct the absorbance value, in which buffer was used to replace DTNB in the sample blank $\left(S_{B}\right)$ and to replace the sample in the reagent blank $\left(R_{B}\right)$.

The concentration of thiol groups $\left(C_{S H}, \mu \mathrm{mol} / \mathrm{g}\right.$ soluble protein $)$ was calculated using the following equation 4 :

$$
C_{S H}=\frac{\left(\frac{A b s}{\varepsilon * \mathrm{Z}}\right) * D F * 10^{6}(\mu \mathrm{mol} / \mathrm{L})}{\text { Soluble protein concentration }(\mathrm{g} / \mathrm{L})} \quad \text { Eq. } 5
$$

Where $A b s$ is the net absorbance value after blank correction $\left(A b s=\right.$ sample $\left.A b s-S_{B}-R_{B}\right), \mathcal{E}$ is the molar extinction coefficient for DTNB $\left(13,600 \mathrm{M}^{-1} \mathrm{~cm}^{-1}\right), z$ the path length, $D F$ is the dilution factor of the sample and $10^{6}$ is to convert $\mathrm{mol} / \mathrm{L}$ to $\mu \mathrm{mol} / \mathrm{L}$.

\subsection{Sodium dodecyl sulphate polyacrylamide gel (SDS-PAGE)}

The molecular weight distribution of proteins in the different samples was assessed by performing SDS-PAGE in non-reducing and reducing conditions according to the manufacturer's specifications. First, the FFSF and DSF supernatants (section 2.6) were diluted to obtain a protein concentration of around $1 \mathrm{~g} / \mathrm{L}$, and the SPI supernatant was diluted to obtain a protein concentration of $2.5 \mathrm{~g} / \mathrm{L}$. For non-reducing conditions, samples were mixed with the 2x Laemmli buffer (1:1). For reducing conditions the sample buffer was prepared by mixing 950 $\mu \mathrm{L}$ of $2 \mathrm{x}$ Laemmli buffer with $50 \mu \mathrm{L}$ of $\beta$-2-mercaptoethanol. Samples were then mixed with the reducing sample buffer $(1: 1)$. All samples were heated at $95{ }^{\circ} \mathrm{C}$ for $5 \mathrm{~min}$ in an Eppendorf thermomixer (Eppendorf AG, Germany) and cooled at room temperature $\left(\sim 25^{\circ} \mathrm{C}\right)$ for $30 \mathrm{~min}$. After cooling down, the samples were centrifuged using $10,000 \mathrm{~g}$ for $5 \mathrm{~min}$. Then, $15 \mu \mathrm{L}$ of samples or molecular weight standard were deposited on top of the gels. The electrophoresis was carried out with a 10x Tris/Glycine/SDS running buffer (25 mM Tris, $192 \mathrm{mM}$ glycine and $0.1 \mathrm{w} / \mathrm{v} \% \mathrm{SDS}$ ) at $200 \mathrm{~V}$ for approximately $30 \mathrm{~min}$. Afterwards, the gels were washed 3 times 
292 with ultrapure water and stained with Bio-safe Coomassie stain overnight. The gels were then

293 washed with ultrapure water for 30 min before scanning using a GS-900 Calibrated

294 Densitometry System (Bio-Rad Laboratories, Inc., USA). The gel images were analyzed using

295 the Image Lab (version 2.0.1, Bio-Rad Laboratories). SDS-PAGE was done in duplicate in 2 296 independent samples.

297 2.11. Protein surface-exposed hydrophobicity

298 The protein surface-exposed hydrophobicity was determined according to Berton-Carabin et al.

299 (2016). Supernatants of samples prepared in $10 \mathrm{mM}$ sodium phosphate buffer $\mathrm{pH}$ 7.0, (section

300 2.6) were diluted to a final concentration of $1 \mathrm{~g} / \mathrm{L}$ soluble protein. A solution of the anionic

301 fluorescence probe 8-anilino-1-napthalensulfonic acid ammonium salt (ANSA) (2.4 mM) was

302 prepared in $10 \mathrm{mM}$ sodium phosphate buffer at $\mathrm{pH} 7.0$ and mixed overnight at $4{ }^{\circ} \mathrm{C}$. The

303 fluorescence emission spectra were measured between 400 and $650 \mathrm{~nm}$ with steps of $0.5 \mathrm{~nm}$

304 using a RF-6000 spectrofluorometer (Shimadzu Corporation, Kyoto, Japan). The excitation

305 wavelength was set at $385 \mathrm{~nm}$ and the emission was measured at $480 \mathrm{~nm}$, with a scan rate of 60

$306 \mathrm{~nm} / \mathrm{min}$ and spectral bandwidth of $5.0 \mathrm{~nm}$. For this measurement, quartz cuvettes with

307 dimensions 10 x $10 \mathrm{~mm}$ were used (Hellma Analytics, Müllheim, Germany). Then $1 \mathrm{~mL}$ of 308 sample was mixed with $10 \mu \mathrm{L}$ ANSA for $1 \mathrm{~min}$ and the spectrum was recorded. ANSA was

309 added to the sample until it reached saturation. The results are expressed as the maximum

310 fluorescence intensity $\left(F_{\max }\right)$ at $480 \mathrm{~nm}$, corrected after blanks subtraction: sample with no

311 ANSA and buffer with the same ANSA concentration. Measurements were done in 2 312 independent samples. 
314 In Fig. 1 we show a schematic representation of the different soy-based ingredients and products 315 prepared, stored and analyzed for lipid and protein oxidation.

\section{$316 \quad$ 2.13. Statistical analysis}

317 All the data are expressed as the mean and standard deviation of independent samples, which 318 were measured in triplicate per experiment, unless otherwise stated. Statistical analysis was done 319 using the Statistical Package for the Social Sciences (SPSS software v. 23, IBM Inc.). One way320 ANOVA with a post hoc Turkey test was done to compare means of carbonyl content of FFSF 321 and DSF stored at different temperatures within the same storage day; carbonyl content of 322 unheated and thermomechanically treated SPI; and means of protein surface-exposed 323 hydrophobicity and thiol groups among soy protein ingredients. T-Test for independent samples 324 was used to compare means of carbonyl content between lab-made SPI and commercial, within 325 the same process conditions. The significance level was set at $p<0.05$.

\section{Results and discussion}

327 First, the effect of storage temperature on the chemical stability of FFSF and DSF was determined over 250 days. This was assessed by measuring primary and secondary lipid oxidation products, and protein-bound carbonyls and protein molecular weight distribution as

330 markers for protein oxidative modifications. Second, the oxidative status of SPI was determined,

331 considering the effects of wet fractionation and of thermomechanical process. 


\subsubsection{Lipid oxidation}

334 The formation of lipid hydroperoxides in the soybean oil extracted from FFSF is shown in Fig.

335 2A. The hydroperoxide concentration in the fresh samples was $2.55 \pm 1.25$ meq. $\mathrm{kg}^{-1}$ of oil, and 336 this concentration did not significantly increase over the 250 days of storage, whatever the storage temperature. The concentration of hydroperoxides in crude soybean oil extracted by organic solvent has been reported to be around 0.6 meq. $\mathrm{kg}^{-1}$ (De Moura Bell et al., 2013) or 2 meq.kg-1 (Alencar et al., 2010). These values correspond to our findings, albeit slightly lower, which could be due to some variability in moisture and lipid content in the soybeans, and in the extraction conditions (Crowe, Crowe, Johnson, \& White et al., 2002). According to the Codex

342 Alimentarius, peroxide values that are considered acceptable for human consumption are up to 10 meq. $\mathrm{kg}^{-1}$ of refined oil and 15 meq. $\mathrm{kg}^{-1}$ of cold pressed and virgin oil (FAO, 1999). This means that the oil present in FFSF stored at different temperatures for up to 250 days is still acceptable according to these standards.

The formation of secondary oxidation products measured by pAV was also minimal over the 250 days of storage, and no effect of temperature was observed (Fig. 2B). The oil extracted from

348 fresh FFSF had a pAV value of $1.13 \pm 0.08$. Likewise, De Moura Bell et al. (2013) found a pAV value of 1.88 for crude soybean oil extracted with an organic solvent. Although lower pAV values of $0.28-0.47$ have been described for vegetable oils, such as rapeseed, sunflower and kiwiseed oil, those were freshly stripped by means of an adsorbent material (Viau, Genot, Ribourg, \& Meynier, 2016). Overall, we can thus conclude that our FFSF was stable to lipid oxidation over the tested storage period, whatever the temperature. This may be due to the low LOX concentration $(\mu \mathrm{mol} / \mathrm{min} / \mathrm{ml}$ enzyme), moisture content and water activity of this 
ingredient (Table S1, supplementary material). In those conditions, lipid oxidation is in fact expected to be low (Schaich et al., 2013).

\subsubsection{Protein-bound carbonyl content}

The protein-bound carbonyl content in FFSF and DSF, measured over 250 days of storage at different temperatures, is shown in Fig. 3. Fresh FFSF had a carbonyl content of $5.87 \pm 1.80$ mmol carbonyls/kg soluble protein (Fig. 3A), which moderately increased over 60 days of storage at room temperature $\left(\sim 25^{\circ} \mathrm{C}\right)$. However, due to variability among batches, this increase was not significant $(p>0.05)$. The differences among batches might be due to the fact that radical chain reactions are auto-catalytic, and inherently difficult to control and reproduce, especially when no catalyst is purposely added (Schaich et al., 2013). Fresh DSF had a carbonyl content of $5.92 \pm 0.76 \mathrm{mmol}$ carbonyls $/ \mathrm{kg}$ soluble protein (Fig. 3B) which did not increase over storage (Fig. 3B). Lower carbonyl content of $2.79 \pm 0.06 \mathrm{mmol}$ carbonyls $/ \mathrm{kg}$ soluble protein was previously reported for full-fat lupin flour submitted to the same milling process as our FFSF and stored for 2 weeks at $20{ }^{\circ} \mathrm{C}$ (Berghout et al. 2015b). Differences in carbonyl content between the full-fat lupin flour and FFSF may be attributed to oil fatty acid composition, as soybean oil usually contains around 50\% polyunsaturated fatty acids and lupine oil only around 30\% (Johnson et al., 2008; Sbihi, Nehdi, Tan, \& Al-Resayes, 2013). Differences in microconstituent composition (e.g., transition metals such as iron) could also play a role.

Furthermore, it is relevant to mention that the carbonyl content was measured in the soluble fraction (i.e., supernatant) of FFSF and DSF, which represents half of the total protein suspended in water (Fig. S2 in supplementary material). Measurement of carbonyls in the non-soluble proteins cannot be accessed by DNPH method. More generally, most of the methods available to monitor general or specific protein oxidation markers give information only on the protein 
fraction that can be re-solubilized, which hampers the characterization of the proteins that cannot, although they may be highly chemically altered.

It is interesting to speculate on the reasons that may explain why FFSF seemed slightly more prone to protein carbonylation upon storage, compared to DSF (Fig. 3). The presence of lipids is the most logical reason, because protein carbonylation is influenced by presence of unsaturated oil and its oxidation level (Cucu et al., 2013). To prove this effect, Cucu et al. (2013) prepared emulsion-based model systems with SPI and different oils, regarding composition and oxidation level. Carbonylation increased from $\sim 3 \mathrm{mmol}$ carbonyls/kg soluble protein to $\sim 12$ mmol carbonyls/kg soluble protein in SPI incubated with highly oxidized soybean oil (pAV value around 94) and fish oil (pAV value around 13) compared to fresh olive oil, sunflower oil and soybean oil with lower oxidation level (pAV value around 4 to 10). Therefore, we assume that the presence of oil in the FFSF contributed to the moderate carbonylation over time. The low levels of oxidation in the oil extracted from FFSF are in line with the limited protein oxidation in those samples.

\subsubsection{Molecular size distribution by SDS-PAGE: FFSF and DSF}

We performed SDS-PAGE to investigate the molecular weight distribution of proteins in FFSF and DSF (Fig. 4), freshly prepared, and upon storage (7, 90 and 250 days at $-20{ }^{\circ} \mathrm{C}$; similar trends were observed at the other temperatures tested, data not shown). All major soy protein subunits, namely $\alpha, \alpha^{\prime}, \beta$ subunits of $\beta$-conglycinin and acidic and basic subunits of glycinin, were present in both soy flours as previously reported (Lamsal \& Johnson, 2007). Bands with high molecular weights such as $100 \mathrm{kDa}$ ascribed to LOX, and those higher than $100 \mathrm{kDa}$ are interpreted as aggregates between $\alpha$ and $\alpha$ ' subunits through disulfide bonds (Qi, Venkateshan, Mo, Zhang, \& Sun, 2011). The presence of aggregates between $\alpha$ and $\alpha^{\prime}$ subunits is in line with the fact that they were not seen any more when the SDS-PAGE was performed in reducing 
conditions (Fig. 4). We did not detect differences among storage days and between FFSF and DSF samples under non-reducing conditions. Therefore, both flours were relatively stable over time with regard to protein molecular weight distributions, without any unexpected aggregation or fragmentation phenomena.

\subsection{Effect of fractionation process on the oxidative status of SPI}

The effect of wet fractionation process on the physicochemical properties of proteins in SPI was assessed by determining protein surface-exposed hydrophobicity, thiol groups, and proteinbound carbonyl content. The molecular weight distribution was determined by SDS-PAGE. We compared our lab-made SPI to a commercial SPI.

The protein surface-exposed hydrophobicity in DSF was lower than that in FFSF, suggesting protein conformational changes induced by the solvent-based extraction. Both the lab-made and commercial SPIs had higher surface-exposed hydrophobicity than FFSF and DSF (Fig.5A), indicating that more hydrophobic segments were exposed in these purified ingredients. Protein conformational changes could be induced by denaturation, but also, protein oxidation can affect the surface-exposed hydrophobicity. For instance, Berton-Carabin et al. (2016) found a decrease in surface-exposed hydrophobicity of whey proteins incubated in prooxidant conditions, which was related to extensive protein aggregation. Even though there was no significant difference in the surface-exposed hydrophobicity observed between the SPI samples (lab-made and commercial), we observed a large variability between the independent lab-made SPI samples obtained from different batches of DSF (Fig. 5A).

The concentration in thiol groups, or free sulfhydryl groups, was similar in FFSF and DSF (Fig. 5B). This shows that the defatting process did not induce thiol oxidation. However, the lab-made SPI had the lowest thiol group concentration, showing that during wet fractionation a loss of thiol groups happened, which may be associated to their oxidation (Rysman et al., 2014). 
Berghout et al.(2015a) reported a slightly lower thiol concentration of $10.6 \mu \mathrm{mol} / \mathrm{g}$ protein in a commercial SPI, using the same method as reported here. Meanwhile, studies on lab-made SPIs have found lower concentrations of thiols, ranging from 3.08 to $8.32 \mu \mathrm{mol} / \mathrm{g}$ protein (Boatright \& Hettiarachchy, 1995; Chen et al., 2013) The broad range in thiol concentration described in the literature can be explained by the biological variability in the starting soybeans, as well as by differences in the processes applied to yield SPI.

We analyzed the protein molecular weight distribution of the SPI samples (lab-made and commercial) by SDS-PAGE under non-reducing and reducing conditions (Fig. 5C). Under non reducing conditions bands between 100 and $150 \mathrm{kDa}$ were observed in both SDS-PAGE profiles of lab-made SPI and commercial SPI, which were less intense under reducing conditions. This indicates that some aggregates were formed and stabilized by disulfide bonds. However, under reducing conditions there was no difference between the SDS-PAGE profiles of the lab-made and commercial SPIs, despite the aforementioned difference in thiol group concentration. It is thus possible that other oxidation products of the thiol groups were formed in the lab-made SPI, or that the extent of disulfide bond formation in this sample was too low to be accurately detected by this method.

The carbonyl content of freshly prepared lab-made SPI was $6.41 \pm 0.63 \mathrm{mmol}$ carbonyls/kg soluble protein (Fig. 5D), which corresponds to an increase of only 8\% compared to the carbonyl content in DSF. Therefore, the fractionation process did not substantially promote carbonylation of soy proteins. Likewise, carbonyl content of $6.4 \mathrm{mmol}$ carbonyls $/ \mathrm{kg}$ soluble protein (Liu, Xiong, \& Butterfield, 2000) and $5.78 \mathrm{mmol}$ carbonyls/kg soluble protein (Chen et al., 2013) has been reported for a lab-made SPI. Conversely, lower carbonyl contents ranging from $1.65 \pm 0.06$ to $4.31 \pm 0.02 \mathrm{mmol}$ carbonyls $/ \mathrm{kg}$ soluble protein were reported for lab-made SPI prepared by wet fractionation (Huang et al., 2006; Wu et al., 2009). Variations in the carbonyl content of 
different lab-made SPIs could be associated with the presence of remaining lipids combined with residual LOX activity, even though a decrease in LOX activity is expected after fractionation process (Huang et al., 2006).

The commercial SPI had a significantly higher carbonyl content than the lab-made SPI, reaching $9.12 \pm 0.25 \mathrm{mmol}$ carbonyls/kg soluble protein (Fig. 5D). Even though the carbonyl content in commercial SPI was higher than in lab-made samples, the variation was somewhat limited considering that different soybeans and processing were used. One of the possible explanations is related to the drying process to obtain the final powder. In large-scale processes, spray-drying is commonly used, which has been shown to promote protein oxidation in pea protein powders (Duque Estrada et al., 2018). In addition, Li et al. (2019) have shown that spray-drying temperature induces protein oxidation in whole milk powders.

\subsection{Effect of thermomechanical process on protein oxidation of SPI}

We finally investigated the effect of a thermomechanical process on protein oxidation in labmade and commercial SPI hydrated powders. The protein-bound carbonyl content was measured as the main marker of protein oxidation, while the molecular weight distribution by SDS-PAGE was used to assess possible protein fragmentation and aggregation (Fig. 6).

The applied shear- and heat-based process at $140{ }^{\circ} \mathrm{C}$ increased the carbonyl content in the labmade SPI sample from $6.41 \pm 0.63$ to $16.47 \pm 0.94 \mathrm{mmol}$ carbonyls $/ \mathrm{kg}$ soluble protein $(157 \%$ increase) (Fig. 6A). This process also increased the carbonyl content in the commercial SPI sample, from $9.12 \pm 0.25$ to $17.36 \pm 1.43 \mathrm{mmol}$ carbonyls $/ \mathrm{kg}$ soluble protein $(90.5 \%$ increase) . At a process temperature of $100{ }^{\circ} \mathrm{C}$, the carbonyl content increased by $52 \%$ and $40.6 \%$ in the lab-made and commercial SPIs, respectively, indicating that the extent of protein carbonylation upon processing is temperature-dependent. Remarkably, the level of carbonyls became similar 
for both SPIs after processing at the highest temperature, despite differences in initial levels (unheated samples). The prooxidant effect of thermomechanical process was previously observed for commercial SPC with increased carbonyl content after hydration and shearing at 100 and $140{ }^{\circ} \mathrm{C}$; however, in that case, there was no effect of the actual temperature (Duque Estrada et al., 2018). In line with these results, Lu et al. (2017) found an increase of $57.5 \%$ in carbonyl content of DSF dry-heated at $100{ }^{\circ} \mathrm{C}$ for $8 \mathrm{~h}$ compared to unheated DSF. Guo, Xiong, Qin, Jian, Huang and Chen (2015) also found that pre-heating SPI suspensions at $80{ }^{\circ} \mathrm{C}$ or 90 ${ }^{\circ} \mathrm{C}$ for 5 to $30 \mathrm{~min}$ before spray drying increased carbonylation compared to spray dried powders with no pre-treatment.

To put these results into perspective, it is worth mentioning that the carbonyl content of processed SPI samples at $100{ }^{\circ} \mathrm{C}$ is similar to values found in meat cooked by different methods but with lower internal temperature. For instance, Hu, Ren, Shen, Chen, Ye and Ling (2017) showed that roasting fish at $200{ }^{\circ} \mathrm{C}$ for $10 \mathrm{~min}$ or frying it at $180{ }^{\circ} \mathrm{C}$ for $5 \mathrm{~min}$ (internal temperature of $85 \pm 5{ }^{\circ} \mathrm{C}$ for both methods) resulted in carbonyls contents around $10 \mathrm{mmol}$ carbonyls/kg soluble protein, representing a 4-fold increase compared to raw fish. In processed meat products, the carbonyl content can also be substantially high. Soladoye et al. (2017) reported a total carbonyl content around $80 \mathrm{mmol}$ carbonyls/kg soluble protein in bacon, which further increased after cooking. The authors explained that the extent of carbonylation may be related to the nature of the raw material, added ingredients and processing of the bacon. It can, therefore, be concluded that the initial disadvantage of plant proteins ingredients with respect to oxidation levels can however be counterbalanced by the fact that meat products, especially processed meat, can contain high oxidation levels as well. These levels can be explained by the fact that meat products usually need a cooking step as well and contain strong prooxidant factors such as heme iron in addition (Filgueras et al., 2011). 
The SDS-PAGE profiles of lab-made and commercial SPIs processed at $140{ }^{\circ} \mathrm{C}$ are shown in fig. 6B. The individual bands are not well-visible anymore, especially the ones corresponding to $\beta$-conglycinin subunits, which is clearly different from the profiles previously depicted for unheated SPIs (Fig. 5C). Likewise, Cucu et al. (2013) showed that $\alpha$ subunits of $\beta$-conglycinin and glycinins' subunits were more prone to oxidation since there was a loss in the intensity of those bands with increased prooxidant concentration. The disappearance of the bands could be a result of protein oxidation inducing irregular covalent protein aggregation and therefore change their molecular weight distribution. Wang, Susan and Wang (2007) showed that all bands either disappeared or were much lighter in SDS-PAGE of preheated SPI at $130{ }^{\circ} \mathrm{C}$ compared to SPI heated at lower temperatures and unheated samples, which the authors attributed to less accumulation in the loading well than samples heated at lower temperatures. Ma et al. (2018) showed that $\alpha$ and $\alpha$ 'subunits of $\beta$-conglycinin were not detected in the SDSPAGE profile of a SPI made from extruded FFSF at 90 and $100{ }^{\circ} \mathrm{C}$. The authors suggested that the proteins with a molecular weight between $48-100 \mathrm{kDa}$ might have been hydrolyzed into molecules of lower molecular weight (Ma et al., 2018). In addition, a similar pattern of faint bands on a SDS-PAGE profile of SPI suspensions heated at $140{ }^{\circ} \mathrm{C}$ was observed in the study of Opazo-Navarrete, Altenburg, Boom and Janseen (2018). The fainted bands were attributed to the formation of large protein-protein complexes that were not able to dissolve in the sample buffer (Opazo-Navarrete et al., 2018). Similar findings were reported for soy and whey proteins after extrusion. The combined heat and shear treatment during extrusion also resulted in the formation of larger protein aggregates that were unable to penetrate the gel and thus resulted in no distinct band separation (Chen, Wei, \& Zhang, 2011).

One of the limitations of this approach is that the DNPH method only measures protein oxidation in the soluble fraction, therefore limiting our findings to only a fraction of our samples. When measuring heated samples, insolubility can be an issue for the identification of protein carbonyls 
using such method. Ideally, forthcoming studies should use a method that identifies protein

523 carbonyls in the total protein sample, i.e., in the soluble and insoluble fractions.

\section{4. Conclusions}

525 Soy flours were chemically stable to lipid and protein oxidation during 250 days of storage in 526 chilled or ambient conditions. When DSF was subjected to wet fractionation to yield SPI, some

527 physicochemical changes pertaining to the proteins were detected, including an increase in 528 surface-exposed hydrophobicity and a decrease in thiol groups. However, no substantial increase 529 in protein carbonylation occurred upon long storage. When SPI was subjected to a 530 thermomechanical treatment mimicking the processes typically used to produce structured plant 531 protein-based products, i.e., at $140{ }^{\circ} \mathrm{C}$, substantial protein oxidation was induced. We thus 532 conclude that the thermomechanical process used to structure the product has a predominant 533 effect in promoting protein carbonylation in plant protein-based foods, implying that the effect 534 of ingredient fractionation is less relevant in that respect. Therefore, to yield soy protein-based 535 products with low protein oxidation level, we recommend to use temperatures lower than 140 $536{ }^{\circ} \mathrm{C}$ for the structuring process.

\section{Acknowledgments}

538 The authors thank the financial support from Conselho Nacional de Desenvolvimento Científico

539 e Tecnológico (CNPq/Brazil) (process number 233663/2014-2).

\section{Conflict of interest}

541 The authors declare that we have no conflict of interest. 


\section{References}

Alencar, E. R. de, Faroni, L. R. D., Peternelli, L. A., Silva, M. T. C. da, \& Costa, A. R. (2010). Influence of soybean storage conditions on crude oil quality. Revista Brasileira de Engenharia Agrícola e Ambiental, 14(3), 303-308. https://doi.org/10.1590/s141543662010000300010

American Association of Cereal Chemists (AACC). (1983). Method 30-25: Crude fat in wheat, corn, and soy flour, feeds, and mixed feeds. https://methods.aaccnet.org/summaries/30-2501.aspx/ Acessed 11 June 2018.

Berghout, J. A. M., Boom, R. M., \& van der Goot, A. J. (2015a). Understanding the differences in gelling properties between lupin protein isolate and soy protein isolate. Food Hydrocolloids, 43, 465-472. https://doi.org/10.1016/j.foodhyd.2014.07.003

Berghout, J. A. M., Marmolejo-Garcia, C., Berton-Carabin, C. C., Nikiforidis, C. V., Boom, R. M., \& van der Goot, A. J. (2015b). Aqueous fractionation yields chemically stable lupin

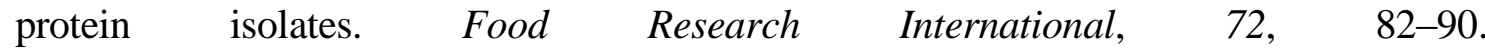
https://doi.org/10.1016/j.foodres.2015.03.039

Berton-Carabin, C. C., Schröder, A., Rovalino-Cordova, A., Schroën, K., \& Sagis, L. (2016). Protein and lipid oxidation affect the viscoelasticity of whey protein layers at the oil - water interface. Eur. J. Lipid Sci. Technol., 118(11), 1630-1643. https://doi.org/10.1002/ejlt.201600066

Boatright, W. L., \& Hettiarachchy, N. S. (1995). Effect of lipids on soy protein isolate solubility. Journal of the American Oil Chemists' Society, 72(12), 1439-1444. https://doi.org/https://doi.org/10.1007/BF02577835

Boatright, W. L., Qingxin, L., \& Jahan, M. S. (2009). Effect of storage conditions on carboncentered radicals in soy protein products. Journal of Agricultural and Food Chemistry, 57(17), 7969-7973. https://doi.org/10.1021/jf900087v

Chen, F. L., Wei, Y. M., \& Zhang, B. (2011). Chemical cross-linking and molecular aggregation of soybean protein during extrusion cooking at low and high moisture content. LWT - Food Science and Technology, 44(4), 957-962. https://doi.org/10.1016/j.lwt.2010.12.008

Chen, N., Zhao, M., Sun, W., Ren, J., \& Cui, C. (2013). Effect of oxidation on the emulsifying properties of soy protein isolate. Food Research International, 52(1), 26-32. https://doi.org/https://doi.org/10.1016/j.foodres.2013.02.028

Crowe, T. D., Crowe, T. W., Johnson, L. A., \& White, P. J. (2002). Impact of extraction method on yield of lipid oxidation products from oxidized and unoxidized walnuts. JAOCS, 
Journal of the American Oil Chemists' Society, 79(5), 453-456. https://doi.org/10.1007/s11746-002-0505-7

Cucu, T., Devreese, B., Kerkaert, B., Mestdagh, F., Sucic, M., Van De Perre, I., \& De Meulenaer, B. (2013). A comparative study of lipid and hypochlorous acid induced oxidation of soybean proteins. LWT - Food Science and Technology, 50(2), 451-458. https://doi.org/https://doi.org/10.1016/j.lwt.2012.08.027

De Moura Bell, J. M. L. N., Maurer, D., Yao, L., Wang, T., Jung, S., \& Johnson, L. A. (2013). Characteristics of oil and skim in enzyme-assisted aqueous extraction of soybeans. JAOCS, Journal of the American Oil Chemists' Society, 90(7), 1079-1088. https://doi.org/10.1007/s11746-013-2248-6

Duque Estrada, P., Berton-Carabin, C. C., Schlangen, M., Haagsma, A., Pierucci, A. P. T. R., \& van der Goot, A. J. (2018). Protein oxidation in plant protein-based fibrous products: effects of encapsulated iron and process conditions. Journal of Agricultural and Food Chemistry, 66(42), 11105-11112. https://doi.org/10.1021/acs.jafc.8b02844

Estévez, M. (2017). What's New in Meat Oxidation? In P. P. Purslow (Ed.), New Aspects of Meat Quality: From Genes to Ethics (1st ed., pp. 91-109). Cambridge: Woodhead Publishing. https://doi.org/10.1016/B978-0-08-100593-4/00006-0

Estévez, Mario, \& Xiong, Y. (2019). Intake of oxidized proteins and amino acids and causative oxidative stress and disease: recent scientific evidences and hypotheses. Journal of Food Science, 84(3), 387-396. https://doi.org/10.1111/1750-3841.14460

FAO. Codex Standard for Named Vegetable Oils CODEX STAN 210-1999. (1999). http://www.fao.org/3/y2774e/y2774e04.htm/ Accessed 22 March 2019.

Filgueras, R. S., Gatellier, P., Ferreira, C., Zambiazi, R. C., \& Santé-Lhoutellier, V. (2011). Nutritional value and digestion rate of rhea meat proteins in association with storage and cooking processes. Meat $\quad$ Science, https://doi.org/10.1016/j.meatsci.2011.02.028

Geerts, M. E. J., Dekkers, B. L., van der Padt, A., \& van der Goot, A. J. (2018). Aqueous fractionation processes of soy protein for fibrous structure formation. Innovative Food Science and Emerging Technologies, 45(September 2017), 313-319. https://doi.org/10.1016/j.ifset.2017.12.002

Guo, F. X., Xiong, Y. L., Qin, F., Jian, H. J., Huang, X. L., \& Chen, J. (2015). Examination of the causes of instability of soy protein isolate during storage through probing of the heatinduced aggregation. JAOCS, Journal of the American Oil Chemists'Society, 92(8), 1075- 

1084. https://doi.org/https://doi.org/10.1007/s11746-015-2684-6

Hellwig, M. (2019). The chemistry of protein oxidation in food. Angewandte Chemie International Edition, 58, 16742-16763. https://doi.org/10.1002/anie.201814144

Hu, L., Ren, S., Shen, Q., Chen, J., Ye, X., \& Ling, J. (2017). Proteomic study of the effect of different cooking methods on protein oxidation in fish fillets. RSC Advances, 7(44), 2749627505. https://doi.org/10.1039/C7RA03408C

Huang, Y., Hua, Y., \& Qiu, A. (2006). Soybean protein aggregation induced by lipoxygenase catalyzed linoleic acid oxidation. Food Research International, 39(2), 240-249. https://doi.org/10.1016/j.foodres.2005.07.012

Jiang, J., Chen, J., \& Xiong, Y. L. (2009). Structural and emulsifying properties of soy protein isolate subjected to acid and alkaline $\mathrm{pH}$-shifting processes. Journal of Agricultural and Food Chemistry, 57, 7576-7583. https://doi.org/10.1021/jf901585n

Johnson, D. R., \& Decker, E. A. (2015). The Role of Oxygen in Lipid Oxidation Reactions: A Review. Annual Review of Food Science and Technology, 6(1), 171-190. https://doi.org/10.1146/annurev-food-022814-015532

Johnson, Lawrence A, White, P. J., \& Galloway, R. (2008). Soybeans: chemistry, production, processing and utilization. ( $1^{\text {st }}$ ed.).Urbana, Illinois: AOCS Press.

Kong, X., Li, X., Wang, H., Hua, Y., \& Huang, Y. (2008). Effect of lipoxygenase activity in defatted soybean flour on the gelling properties of soybean protein isolate. Food Chemistry, 106, 1093-1099. https://doi.org/10.1016/j.foodchem.2007.07.050

Lamsal, B. P., \& Johnson, L. A. (2007). Separating oil from aqueous extraction fractions of soybean. JAOCS, Journal of the American Oil Chemists' Society, 84(8), 785-792. https://doi.org/10.1007/s11746-007-1090-0

Li, B., Mo, L., Yang, Y., Zhang, S., Xu, J., Ge, Y., Xu, Y., Shi, Y., \&Le, G. (2019). Processing milk causes the formation of protein oxidation products which impair spatial learning and memory in rats. RSC Advances, 9(39), 22161-22175. https://doi.org/10.1039/c9ra03223a

Liu, G., Xiong, Y. L., \& Butterfield, D.A. (2000). Chemical, physical, and gel-forming properties of oxidized myofibrils and whey- and soy-protein isolates. Journal of Food Science, $\quad$ 65(5), $\quad$ 811-818. $\quad$ https://doi.org/https://doi.org/10.1111/j.13652621.2000.tb13592.x

Lu, P., Zhang, X. L., Xue, W. Y., Wu, D. W., Ding, L. R., Wen, C., \& Zhou, Y. M. (2017). The protein oxidation of soybean meal induced by heating decreases its protein digestion in vitro and impairs growth performance and digestive function in broilers. British Poultry 
Science, 58(6), 704-711. https://doi.org/https://doi.org/10.1080/00071668.2017.1370535

Ma, W., Xie, F., Zhang, S., Wang, H., Hu, M., Sun, Y., Zhong, M, Zhu, J.,Qi, B., \& Li, Y. (2018). Characterizing the structural and functional properties of soybean protein extracted from full-fat soybean flakes after low-temperature dry extrusion. Molecules, 23(12), 3265. https://doi.org/https://doi.org/10.3390/molecules23123265

Opazo-Navarrete, M., Altenburg, M. D., Boom, R. M., \& Janssen, A. E. M. (2018). The effect of gel microstructure on simulated gastric digestion of protein gels. Food Biophysics, 13(2), 124-138. https://doi.org/10.1007/s11483-018-9518-7

Qi, G., Venkateshan, K., Mo, X., Zhang, L., \& Sun, X. S. (2011). Physicochemical properties of soy protein: Effects of subunit composition. Journal of Agricultural and Food Chemistry, 59(18), 9958-9964. https://doi.org/10.1021/jf201077b

Rysman, T., Jongberg, S., Van Royen, G., Van Weyenberg, S., De Smet, S., \& Lund, M. N. (2014). Protein thiols undergo reversible and irreversible oxidation during chill storage of ground beef as detected by 4,4'-dithiodipyridine. Journal of Agricultural and Food Chemistry, 62(49), 12008-12014. https://doi.org/10.1021/jf503408f

Santé-Lhoutellier, V., Astruc, T., Marinova, P., Greve, E., \& Gatellier, P. (2008). Effect of meat cooking on physicochemical state and in vitro digestibility of myofibrillar proteins. Journal of Agricultural and Food Chemistry, 56(4), 1488-1494. https://doi.org/10.1021/jf072999g Sbihi, H. M., Nehdi, I. A., Tan, C. P., \& Al-Resayes, S. I. (2013). Bitter and sweet lupin (Lupinus albus L.) seeds and seed oils: A comparison study of their compositions and physicochemical properties. Industrial Crops and Products, 49, 573-579. https://doi.org/10.1016/j.indcrop.2013.05.020

Schaich, K. M., Shahidi, F., Zhong, Y., \& Eskin, N. A. M. (2013). Lipid Oxidation.In N. A. M., Eskin, \& F. Shahidi (Eds.), Biochemistry of Foods (pp. 419-478). USA:Academic Press. https://doi.org/10.1016/B978-0-08-091809-9.00011-X

Soladoye, O. P., Shand, P., Dugan, M. E. R., Gariépy, C., Aalhus, J. L., Estévez, M., \& Juárez, M. (2017). Influence of cooking methods and storage time on lipid and protein oxidation and heterocyclic aromatic amines production in bacon. Food Research International, 99(May), 660-669. https://doi.org/10.1016/j.foodres.2017.06.029

Soyer, A., Özalp, B., Dalmiş, Ü., \& Bilgin, V. (2010). Effects of freezing temperature and duration of frozen storage on lipid and protein oxidation in chicken meat. Food Chemistry, 120(4), 1025-1030. https://doi.org/10.1016/j.foodchem.2009.11.042

Utrera, M., Parra, V., \& Estévez, M. (2014). Protein oxidation during frozen storage and 
subsequent processing of different beef muscles. Meat Science, 96(2), 812-820. https://doi.org/10.1016/j.meatsci.2013.09.006

Viau, M., Genot, C., Ribourg, L., \& Meynier, A. (2016). Amounts of the reactive aldehydes, malonaldehyde, 4-hydroxy-2-hexenal, and 4-hydroxy-2-nonenal in fresh and oxidized edible oils do not necessary reflect their peroxide and anisidine values. European Journal of Lipid Science and Technology, 118, 435-444. https://doi.org/10.1002/ejlt.201500103

Wang, Y., Sun, X. S., \& Wang, D. (2007). Effects of preheating treatment on thermal property and adhesion performance of soy protein isolates. Journal of Adhesion Science and Technology, 21(15), 1469-1481. https://doi.org/10.1163/156856107782844756

Wu, W., Zhang, C., \& Hua, Y. (2009). Structural modification of soy protein by the lipid peroxidation product malondialdehyde. Journal of the Science of Food and Agriculture, 89, 1416-1423. https://doi.org/10.1007/s00217-009-1113-1

Xing, Q., Wit, M. De, Kyriakopoulou, K., Boom, R. M., \& Schutyser, M. A. (2018). Protein enrichment of defatted soybean flour by fine milling and electrostatic separation. Innovative Food Science \& Emerging Technologies, 50, 42-49. https://doi.org/10.1016/j.ifset.2018.08.014 
691 Figure 1. Schematic representation of the study design. Blue boxes represents the samples 692 that we analyzed. Darker blue boxes represents samples that were stored for 250 days at room 693 temperature $\left(\sim 25^{\circ} \mathrm{C}\right), 4^{\circ} \mathrm{C}$ and $-20^{\circ} \mathrm{C}$. White arrows indicates processing and grey arrows 694 indicates oxidation measurements. SPI: soy protein isolate.

695 Figure 2. Hydroperoxide concentration $\left(\mathrm{C}_{\mathrm{HPX}}\right.$, meq. $\mathrm{kg}^{-1}$ oil) $(\mathrm{A})$ and $\mathrm{p}$-anisidine value (pAV) 696 (B) of soybean oil contained in full-fat soy flour during 250 days of storage at room temperature 697 (RT) $\left(\sim 25^{\circ} \mathrm{C}\right), 4{ }^{\circ} \mathrm{C}$ and $-20{ }^{\circ} \mathrm{C}$. Data points represent mean $(\mathrm{n}=2$ independent batches, 698 measured in triplicate) and standard deviations shown as error bars. Data points at 190 and 250 699 days represent results of 1 batch measured in triplicate. The dotted line represents acceptable $700 \mathrm{C}_{\mathrm{HPX}}$ for edible vegetable oils according to Codex Alimentarius (A).

701 Figure 3. Carbonyl content per soluble protein ( $\mathrm{mmol} / \mathrm{kg})$ in full-fat soy flour (A) and defatted 702 soy flour (B) stored for 250 days at room temperature (RT) $\left(\sim 25{ }^{\circ} \mathrm{C}\right), 4{ }^{\circ} \mathrm{C}$ and $-20{ }^{\circ} \mathrm{C}$. Data 703 points represent mean and standard deviations are shown as error bars $(n=4$ independent batches 704 of FFSF and 2 independent batches of DSF, measured in triplicate).

705 Figure 4. SDS-PAGE of FFSF (A) and DSF (B) fresh and stored for 7, 90 and 250 days at -20

$706{ }^{\circ} \mathrm{C}$, under non-reducing and reducing conditions M: molecular weight marker; d: days of storage, $707 \alpha / \alpha^{\prime} / \beta$ : subunits of $\beta$-conglycinin. 
708 Figure 5. (A) Maximum fluorescence intensity $\left(F_{\max }\right)$ of the ANSA probe at $480 \mathrm{~nm}$, 709 indicative of the protein surface-exposed hydrophobicity and (B) thiol group concentration

$710(\mu \mathrm{mol} / \mathrm{g}$ soluble protein) of FFSF, DSF, lab-made SPI (SPI-lab) and commercial SPI (SPI

711 C). (C) SDS-PAGE of SPI samples; M: molecular weight marker; $\alpha / \alpha / \beta$ : subunits of $\beta$ 712 conglycinin. (D) Carbonyl content of lab-made SPI and commercial SPI. Results are 713 expressed as mean and standard deviation (error bars) $(\mathrm{n}=3$ independent lab-made SPI 714 samples and 2 independent commercial SPI samples, measured in triplicate).

715 Figure 6. (A) Carbonyl content per soluble protein $(\mathrm{mmol} / \mathrm{kg})$ of unheated and heated lab716 made SPI (SPI-Lab) and commercial SPI (SPIC). Results are expressed as mean and standard 717 deviation (error bars) $(\mathrm{n}=3$ independent SPI-lab and 2 independent SPI C, all measured in 718 triplicate). Different letters stand for a significant difference between SPI samples within the 719 same condition $(p<0.05)$. (B) SDS-PAGE profiles under reducing conditions of lab-made 720 SPI and commercial SPI thermomechanically treated at $140{ }^{\circ} \mathrm{C} . \mathrm{M}$ : molecular weight marker; $721 \alpha / \alpha^{\prime} / \beta$ : subunits of $\beta$-conglycinin. 


\section{Highlights}

- Full-fat and defatted soy flours were oxidatively stable over 250 days storage.

- Wet fractionation did not promote significant protein carbonylation in SPI.

- Thiol groups are oxidized during the fractionation process of SPI.

- Thermomechanical processing of SPI is a main factor for protein carbonylation. 
Figure 1

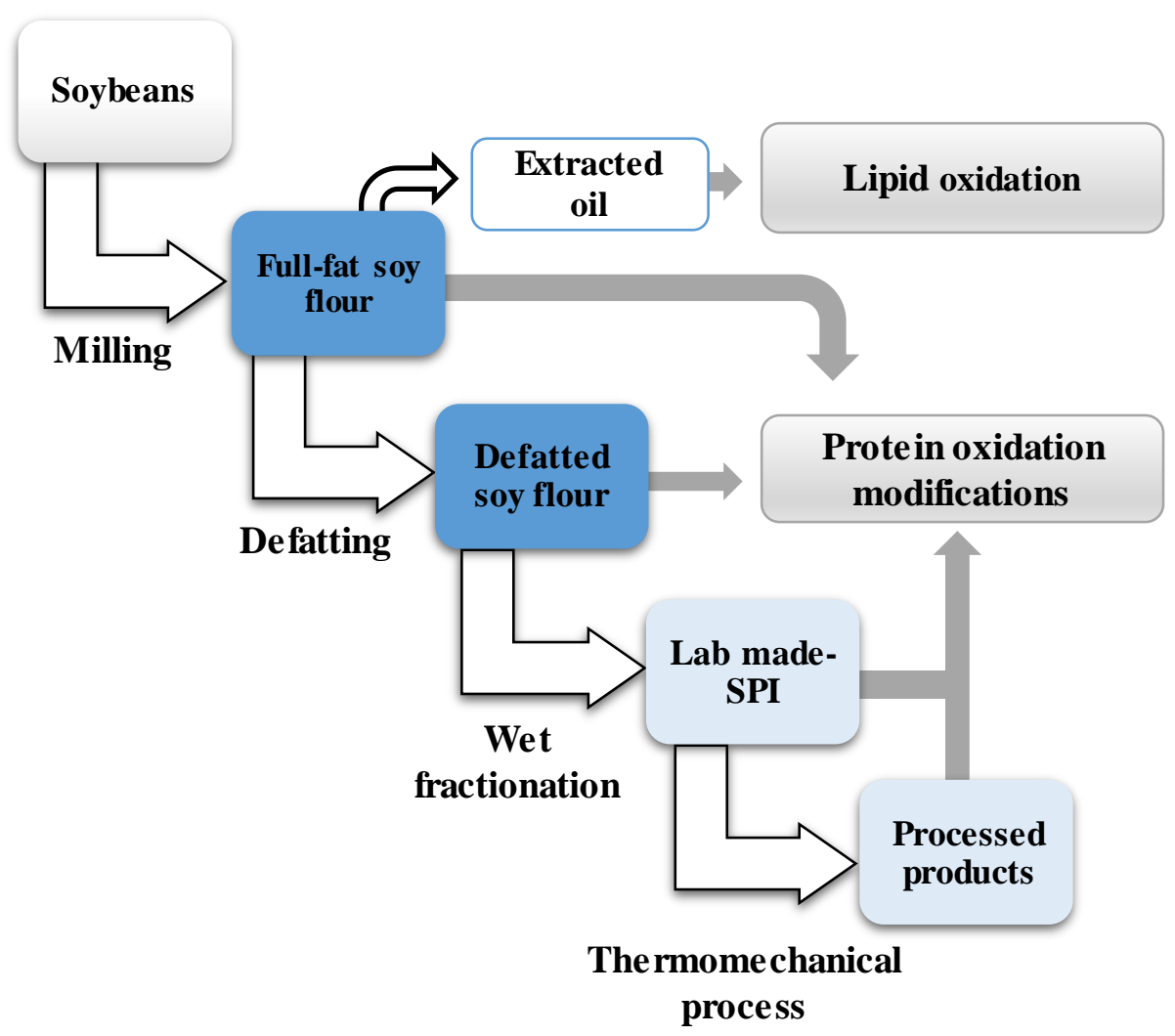


Figure 2

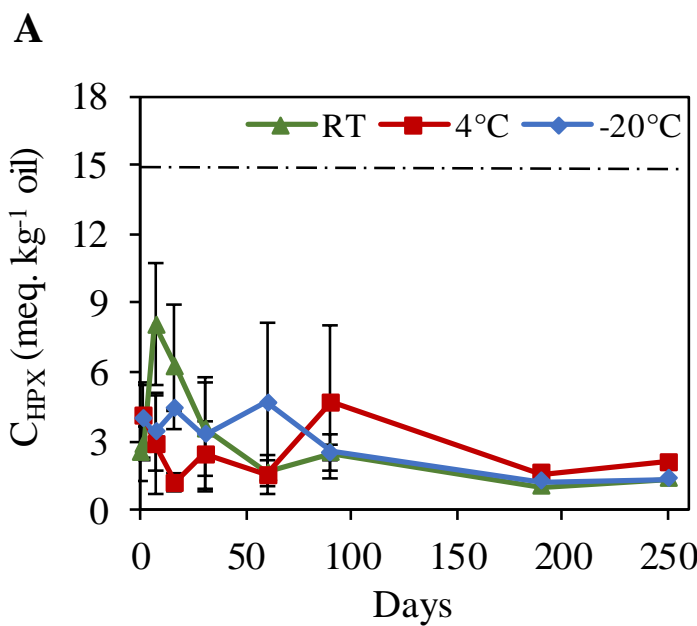

B

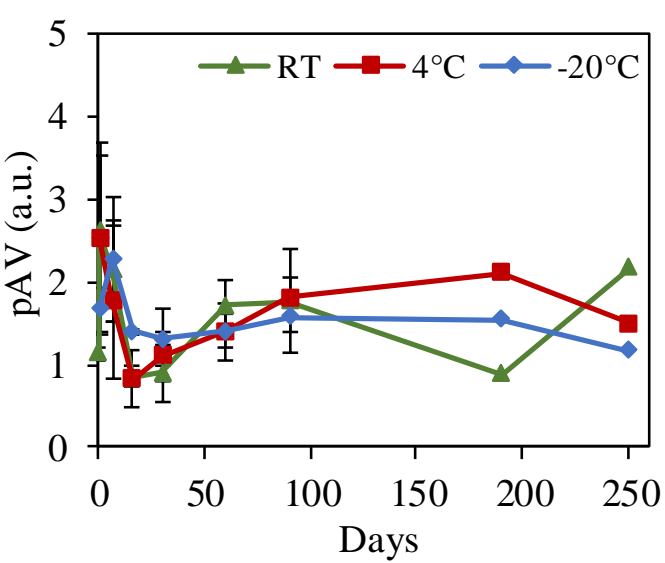


Figure 3

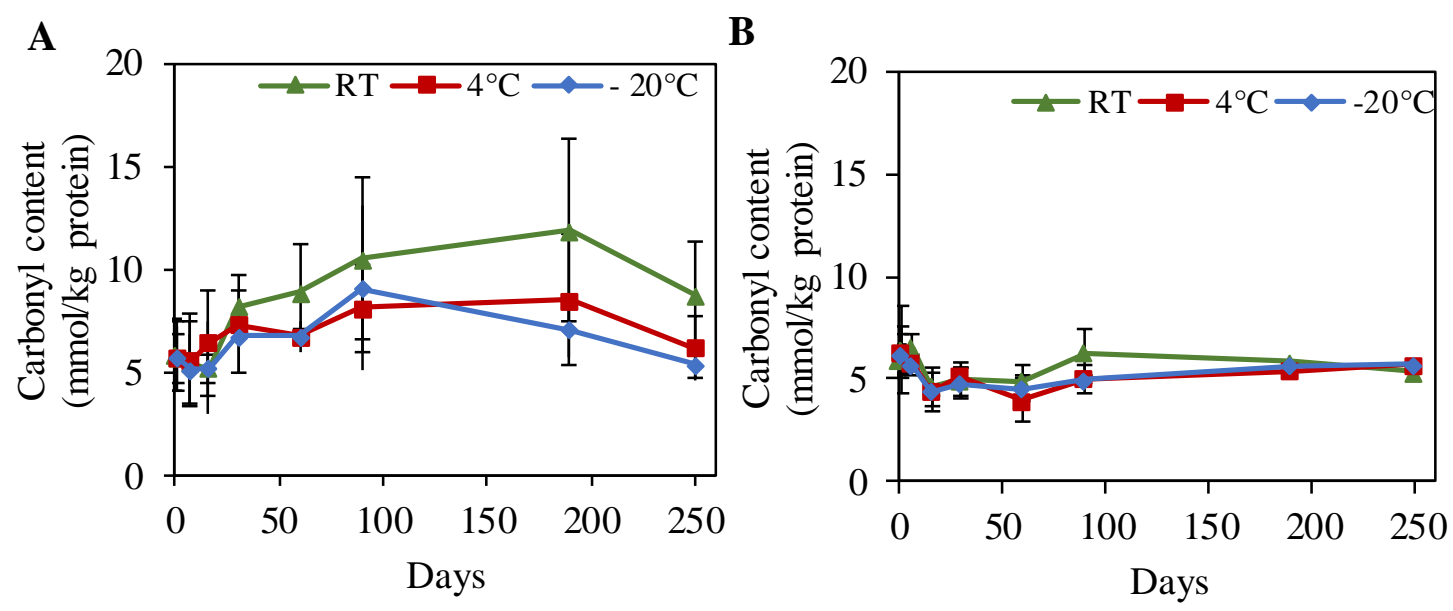


Figure 4

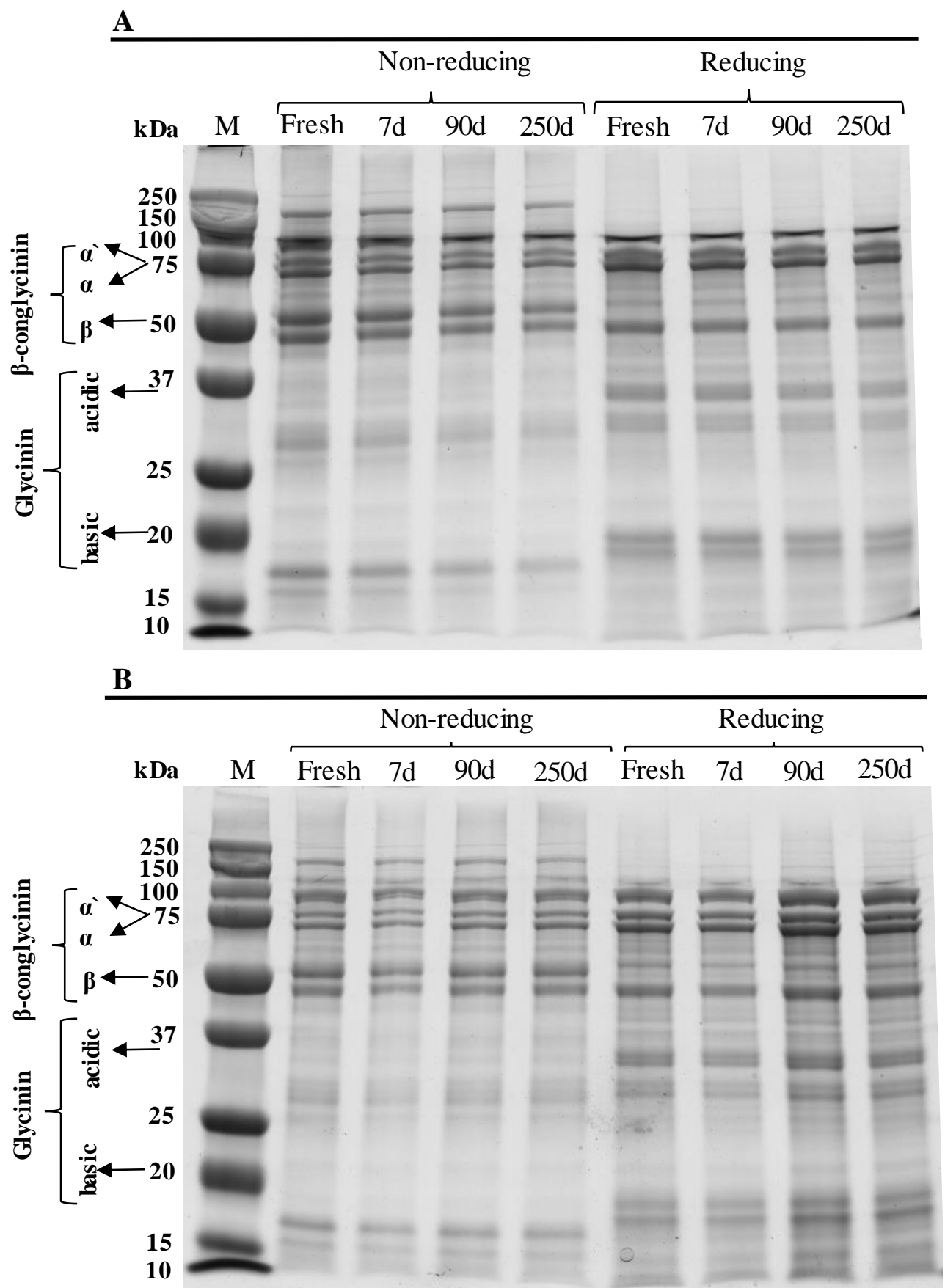




\section{Figure 5}
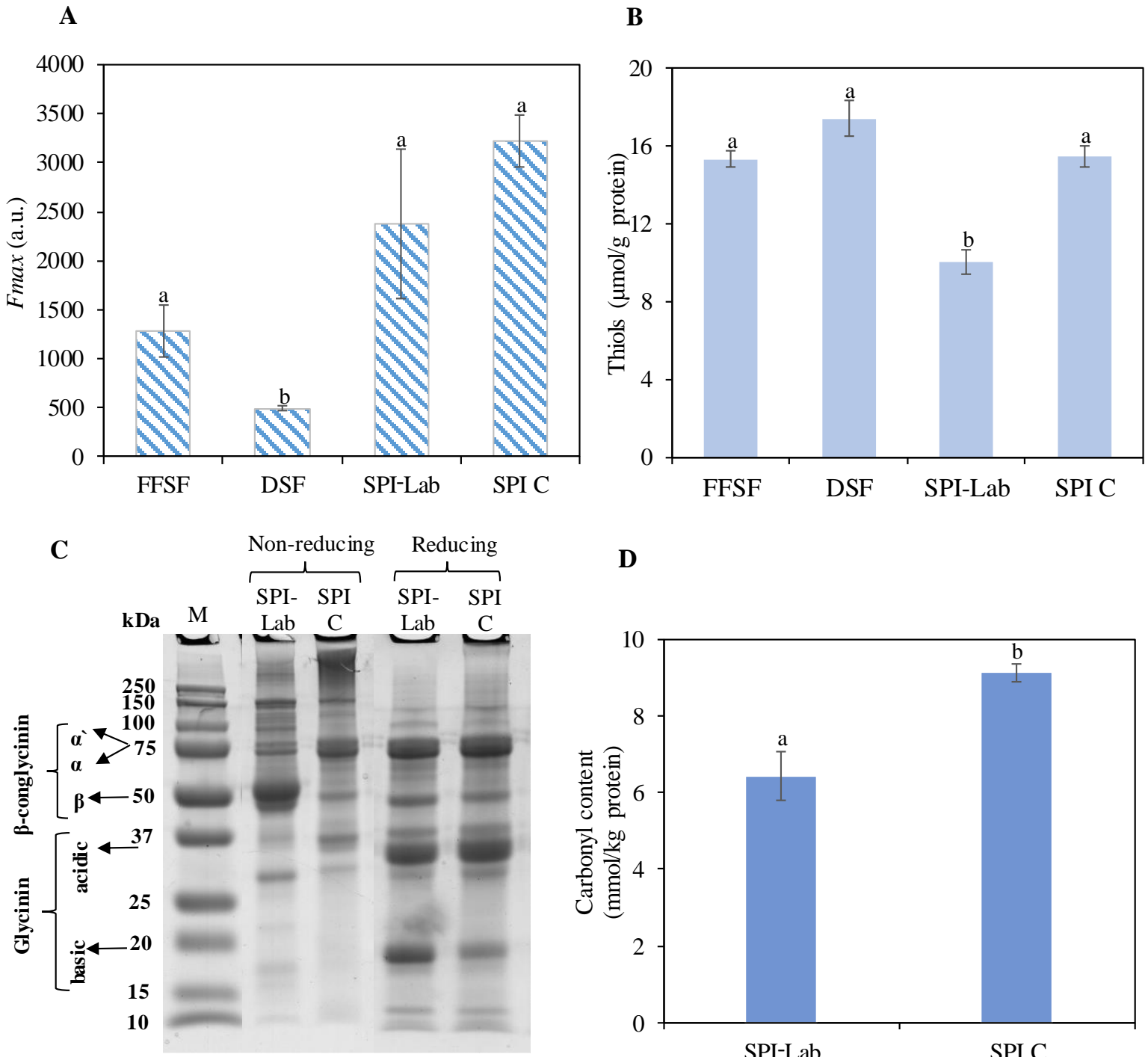

\section{D}

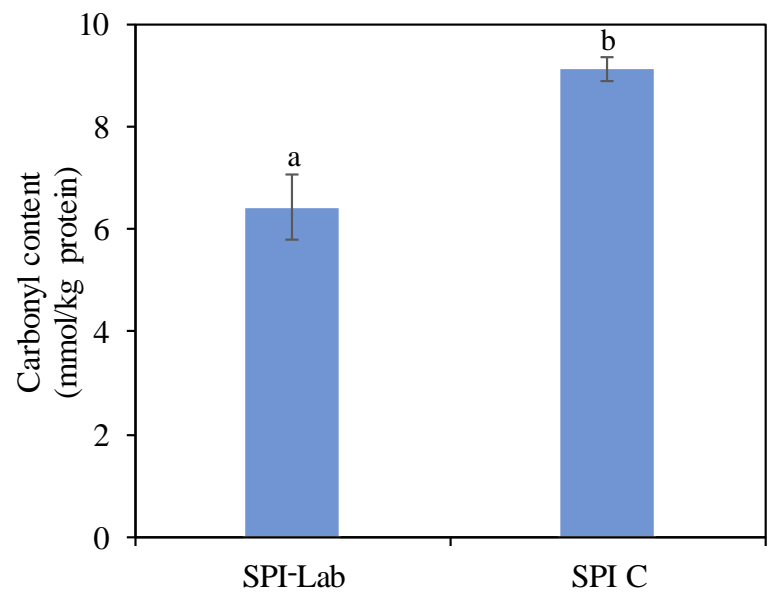


Figure 6

A

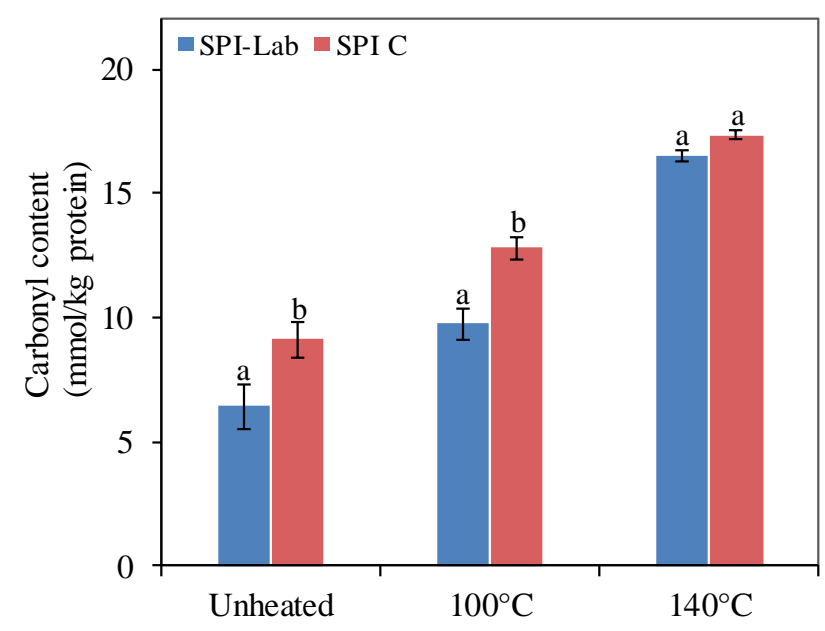

B $\quad$ kDa M SPI.C SPI-Lab

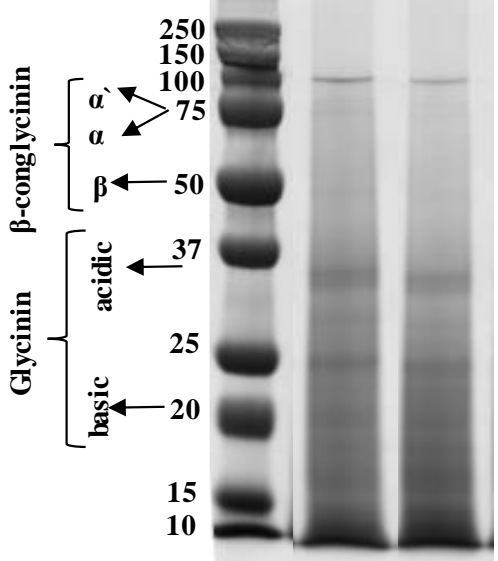




\section{Appendix. Supplementary material}

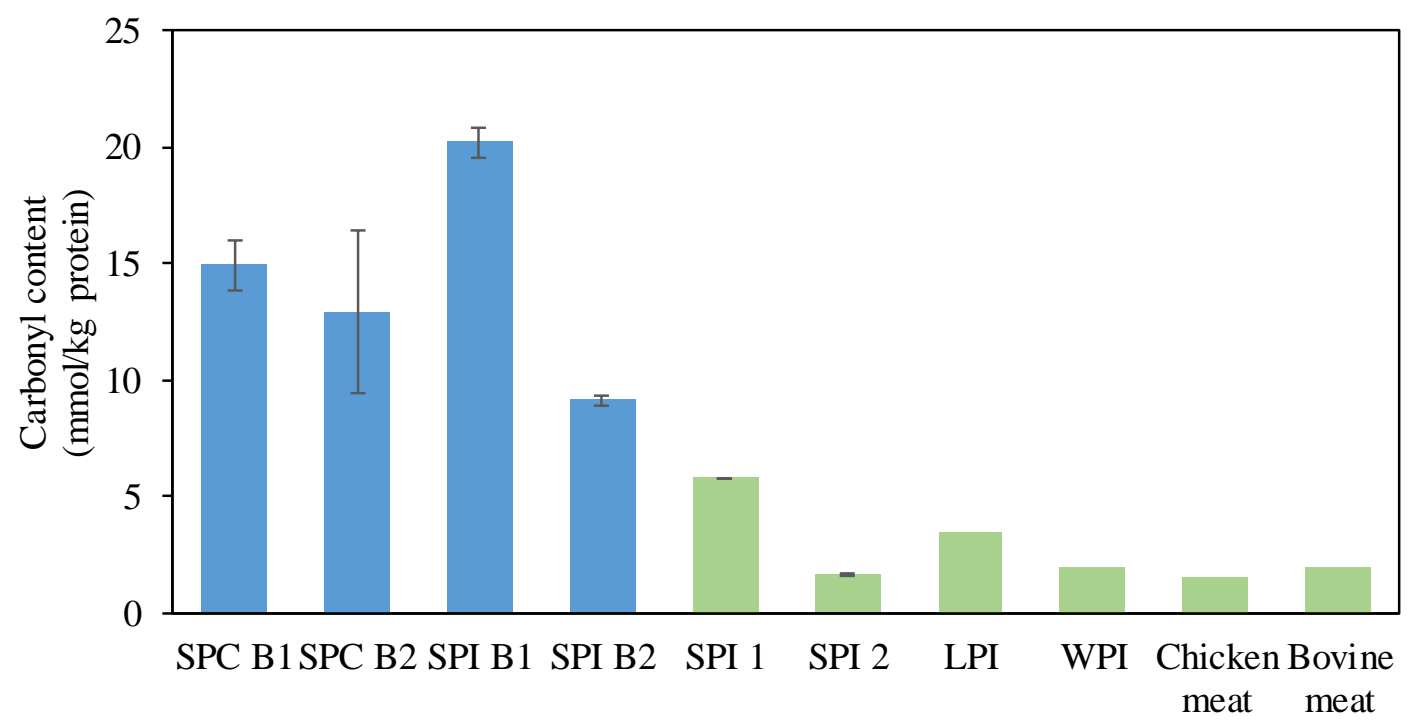

Figure S1. Carbonyl content ( $\mathrm{mmol} / \mathrm{kg}$ soluble protein) in different protein sources. The blue bars represent carbonyl contents measured in our lab: commercial soy protein concentrate (SPC) and soy protein isolate (SPI). SPC B1 (Duque Estrada et al., 2018); SPC B2 and SPI B1 (Duque-Estrada et al., 2019) and SPI B2 is the one described in this paper. The green bars represent data from literature: lab made SPI 1 (Chen et al., 2013a) and SPI 2 (Wu et al., 2009b); lupin protein isolate (LPI) lab-made (Berghout et al., 2015b); commercial whey protein isolate (WPI) (Berton-Carabin et al., 2016); raw chicken meat (Soyer et al., 2010) and raw bovine meat (Santé-Lhoutellier et al., 2008). B: batch. Results are expressed as mean and standard deviation as error bars, when the information was given. 
Table S1. Physical and chemical characterization of full-fat soy flour (FFSF), defatted soy flour (DSF), lab-made SPI (SPI-Lab) and commercial SPI (SPI C).

\begin{tabular}{ccccccc}
\hline $\begin{array}{c}\text { Soy-based } \\
\text { flours }\end{array}$ & Protein (\%) & Moisture (\%) & $\mathbf{a}_{\mathbf{w}}$ & Lipid (\%) & Ash (\%) & $\begin{array}{c}\text { LOX activity } \\
\text { (U/ml) }\end{array}$ \\
\hline FFSF & $38.81 \pm 1.03$ & $7.73 \pm 0.51$ & $0.44 \pm 0.04$ & $21.68 \pm 0.48$ & $3.84 \pm 0.00$ & $106.92 \pm 0.00$ \\
DSF & $46.71 \pm 0.59$ & $8.44 \pm 0.22$ & $0.42 \pm 0.01$ & $0.70 \pm 0.33$ & $5.02 \pm 0.00$ & $106.92 \pm 0.00$ \\
SPI-Lab & $75.31 \pm 1.02$ & $3.32 \pm 0.64$ & $0.68 \pm 0.08$ & ND & $4.39 \pm 0.01$ & ND \\
SPI C & $80.16 \pm 0.67$ & $6.61 \pm 0.61$ & $0.42 \pm 0.00$ & ND & $4.67 \pm 0.58$ & ND \\
\hline
\end{tabular}

Results are expressed as mean and standard deviation. ND: not determined.
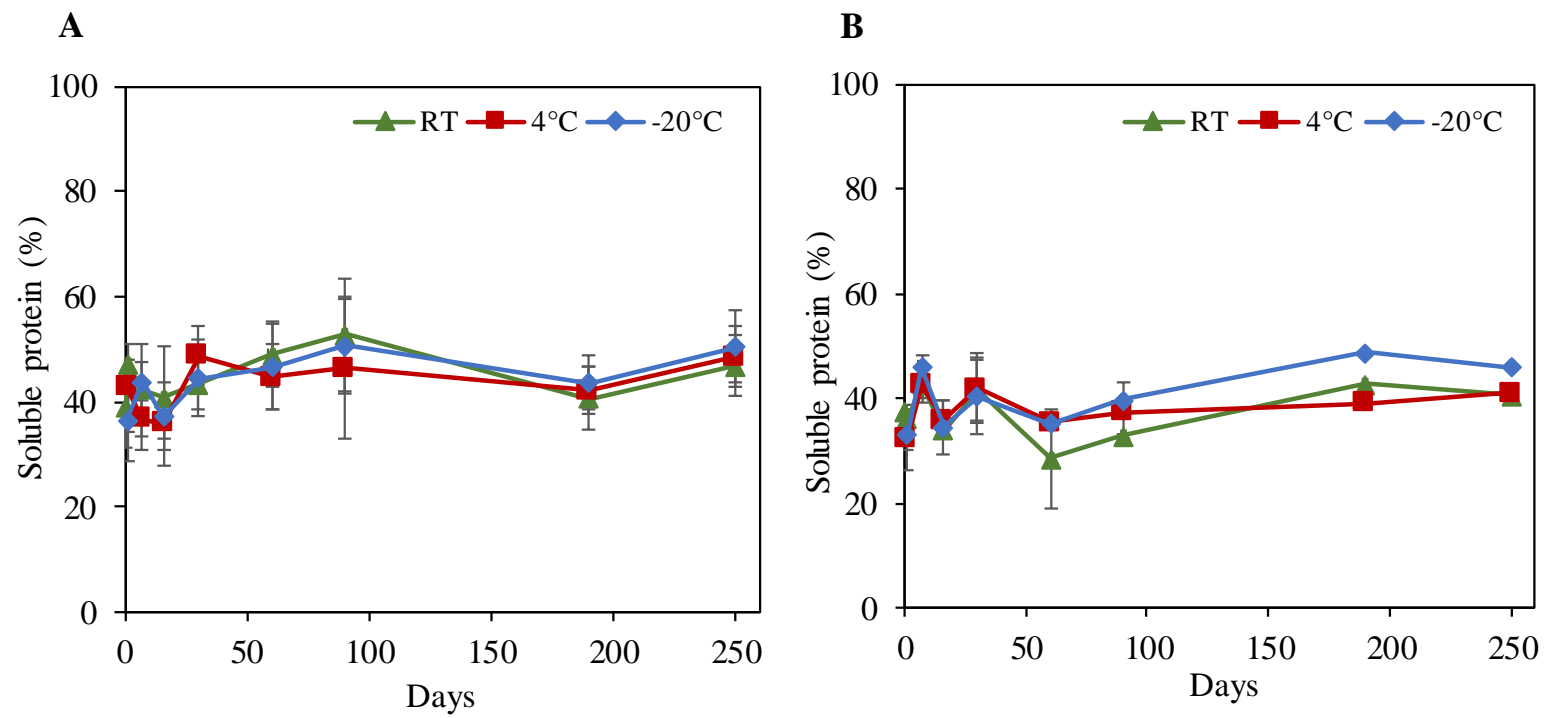

Figure S2. Soluble protein percentage of the supernatant obtained from protein suspensions of full-fat soy flour (A) and defatted soy flour (B) stored at room temperature (RT), $4{ }^{\circ} \mathrm{C}$ and -20 ${ }^{\circ} \mathrm{C}$ for 250 days. Data points represent mean and standard deviations are shown as error bars $(\mathrm{n}=$ 4 independent batches of FFSF and 2 independent batches of DSF). 


\section{References}

Berghout, J. A. M., Marmolejo-Garcia, C., Berton-Carabin, C. C., Nikiforidis, C. V., Boom, R. M., \& van der Goot, A. J. (2015). Aqueous fractionation yields chemically stable lupin protein isolates. Food Research International, 72, 82-90.

Berton-Carabin, C. C., Schröder, A., Rovalino-Cordova, A., Schroën, K., \& Sagis, L. (2016). Protein and lipid oxidation affect the viscoelasticity of whey protein layers at the oil - water interface. Eur. J. Lipid Sci. Technol., 118(11), 1630-1643.

Chen, N., Zhao, M., Sun, W., Ren, J., \& Cui, C. (2013). Effect of oxidation on the emulsifying properties of soy protein isolate. Food Research International, 52(1), 26-32.

Duque-Estrada, P., Berton-Carabin, C. C., Nieuwkoop, M., Dekkers, B. L., Janssen, A. E. M., \& van der Goot, A. J. (2019). Protein Oxidation and In Vitro Gastric Digestion of Processed Soy-Based Matrices. Journal of Agricultural and Food Chemistry, acs.jafc.9b02423.

Duque Estrada, P., Berton-Carabin, C. C., Schlangen, M., Haagsma, A., Pierucci, A. P. T. R., \& van der Goot, A. J. (2018). Protein Oxidation in Plant Protein-Based Fibrous Products: Effects of Encapsulated Iron and Process Conditions. Journal of Agricultural and Food Chemistry, 66(42), 11105-11112.

Soyer, A., Özalp, B., Dalmiş, Ü., \& Bilgin, V. (2010). Effects of freezing temperature and duration of frozen storage on lipid and protein oxidation in chicken meat. Food Chemistry, 120(4), 1025-1030.

Wu, W., Zhang, C., \& Hua, Y. (2009). Structural modification of soy protein by the lipid peroxidation product malondialdehyde. Journal of the Science of Food and Agriculture, $89,1416-1423$. 